\author{
José Manuel Macedo BOTELHO, \\ Iveta MIETULE, \\ Hanna PURIY, \\ Irina MAKSYMOVA, \\ Volodymyr KULISHOV
}

\title{
ECONOMIC DIPLOMACY STRATEGY FOR THE RECOVERY OF THE SLOWDOWN OF GLOBALIZATION (SLOWBALIZATION)
}

\begin{abstract}
The article investigates a transition from globalization to its more restricted model called «slow stabilization» or «slowbalization» in the context of the most decisive challenge to economic diplomacy. The authors of this study identify the problems of globalization, outline possible causes and consequences, and con-

(C) José Manuel Macedo Botelho, Iveta Mietule, Hanna Puriy, Irina Maksymova, Volodymyr Kulishov, 2021.

Botelho, José Manuel Macedo, PhD, University of Evora, Portugal. ORCID: 0000-0002-4001-6563 Email: jmmbinternationalization@gmail.com.

Mietule, Iveta, Dr.oec., Professor, Faculty of Economics and Management, Rezekne Academy of Technologies, Latvia. ORCID: 0000-0001-7662-9866 Email: mietule@inbox.Iv.

Puriy, Hanna, PhD, Associate Professor, State University of Economics and Technology, Ukraine. ORCID: 0000-0003-4226-4445 Email: puriy_av@ kneu.dp.ua.

Maksymova, Irina, PhD, Associate Professor, Department of International Economics, State University of Economics and Technology, Ukraine. ORCID: 0000-0001-9754-0414 Email: maksimova_ii@kneu.dp.ua. Kulishov, Volodymyr, Dr.oec., Professor, Department of International Economics, State University of Economics and Technology, Ukraine. ORCID: 0000-0002-8527-9746 Email: kulishov_vv@kneu.dp.ua.
\end{abstract}


sider the option of returning to comprehensive protectionism as a manifestation of the economic diplomacy of national economic systems in the context of globalization and «slowbalization". The novelty of this work is in using economic diplomacy, in the unique pandemic context, as a driver to support economic recovery, helping to define national and international policies and creating a strong network where government, embassies, consulates, agencies, institutions, companies and households can come together to achieve effective cooperation. The research concludes that economic diplomacy in general, and export promotion agencies in particular, encourage export promotion and trade growth. Authors establish that the strategy of economic diplomacy is the driver of recovery and can assist in the scenario of deceleration defining a clear export strategy, creating a large network that involves all actors and network of offices abroad to spread the exports policy, and employing a wide variety of instruments, such as bilateral, regional, and multilateral agreements.

\section{Key words:}

globalization; slowbalization; protectionism; economic diplomacy; export promotion agencies (EPAs).

JEL: F63, F68, O40.

4 figures, 2 tables, 28 references.

\section{Literature Review and Problem Statement}

There is no doubt, the world economy is going through a difficult transition from globalization to slowbalization, while the tension between economic nationalism and globalization intensifies, which shapes up to be one of the most decisive challenges for economic diplomacy.

Despite the considerable and increasing scientific interest in globalization issues and wide exploration of diplomatic paradigm, the problem of economic di- 

of the slowdown of globalization (slowbalization)

plomacy is usually considered from political point of view and grounded in international relations. In the last decade, there has been a shift in the global economy from comprehensive globalization to more restrained "slowbalization" (Bakas, 2015). Moreover, economic diplomacy is being recognized as having an impact on economic development because it can remove barriers and open markets and export promotion agencies take an active role in facilitating trade growth (Bergeijk et al., 2011).

Economic diplomacy is led by the government and supported by its national and international network consisting of embassies, consulates, agencies, and business support institutions (Bayne \& Woolcock, 2016; Okano-Heijmans, 2011). The government and its economic diplomacy network get in touch with companies (domestic and foreign) to boost investment and export trade (Saner \& Yiu, 2003). Several articles have highlighted the robust link between economic diplomacy and trade (van Bergeijk, 2009).

According to O. Sharov (2018), globalization processes encourage the new players to enter the "diplomatic field», which largely transforms the determinants of classical diplomacy and emphasizes the importance of economic diplomacy. It is natural to assume that the processes of globalization have a transformative effect on the range of diplomatic relations. Economic diplomacy becomes an integral part of the global economy.

A study of the countries' experience conducted by Flissak K. (2015) has shown significant correlation between the macroeconomic performance of the country and the «quality» of its economic diplomacy. Thus, global economic indicators and international markets should be considered in the context of diplomatic environment.

Many scientists admit that the pandemic crisis has dramatically exacerbated the slowdown in globalization in the world economy and in almost world regions (Knoema, 2020; Gygli et al., 2019). Meanwhile, economic diplomacy provides a precious practical methodology for the recovery under the crisis while the slowdown in globalization is caused by a unique crisis in the modern world - a health crisis - and urgent national and international policies must be introduced to protect businesses and families and increase trade growth.

In view of this fact, the national governments require the strategy of economic diplomacy focusing on recovering and rebuilding in the context of slowbalization. The export promotion agencies (EPAs) could be an effective tool aimed at encouraging such strategy. However, the application of EPAs needs additional exploration under the purpose of economic recovery.

The aim of the research. The primary objective of this study is to determine the role of economic diplomacy strategy in reversing the slowdown of the globalization. The research objectives to be investigated are related to the export promotion agencies: 
1. The relationship between EPAs and the impact on export promotion;

2. The relationship between EPAs and the impact on the company's ability to enter and survive in foreign markets;

3. The relationship between EPAs and the impact on geographic and product diversification;

4. The relationship between EPAs and the effect on the competences of small businesses;

5. The relationship between economic diplomacy through embassies and consulates and the impact on the exports.

\section{Methodology of Research}

The qualitative approach is part of this study, taking into account the context and scope of the research. A qualitative investigation is more appropriate for this study due to the objective of understanding and interpreting this phenomenon. The data used for this investigation is provided by several sources, including books, academic journals and publications.

\section{Research Results}

Globalization can be defined as the free worldwide flow of goods, services, data, capital and technology (Milanovic, 2012; Campbell, 1994). Three main reasons helped globalization to reach pre-pandemic crisis levels: (a) liberalization of trade and the elimination of cross-border barriers; (b) economic integration and elimination of controls and; (c) advances in technology and infrastructure (transport, roads, ports, airports) and lower communication costs. These improvements have reduced the barriers of time and distance and give the impression of a «smaller world» (Oxford Economics, 2011; Dicken, 1992). Figure 1 shows five periods and two waves of modern globalization in accordance with the values of the Trade Openness Index (Ortiz-Ospina \& Beltekian, 2018), which is defined as the ratio: [(world exports + world imports)/world GDP].

The first wave of globalization ended with the start of the First World War, when liberalism declined and nationalism increased, leading to a drop in international trade. Figure 1 shows a great drop in the inter-war period. The second wave started after the Second World War. In the post-war period, figure 1 reflects steady growth that lasted until 2010, after which there was a decline. 
Figure 1

\section{Periods of modern globalization}

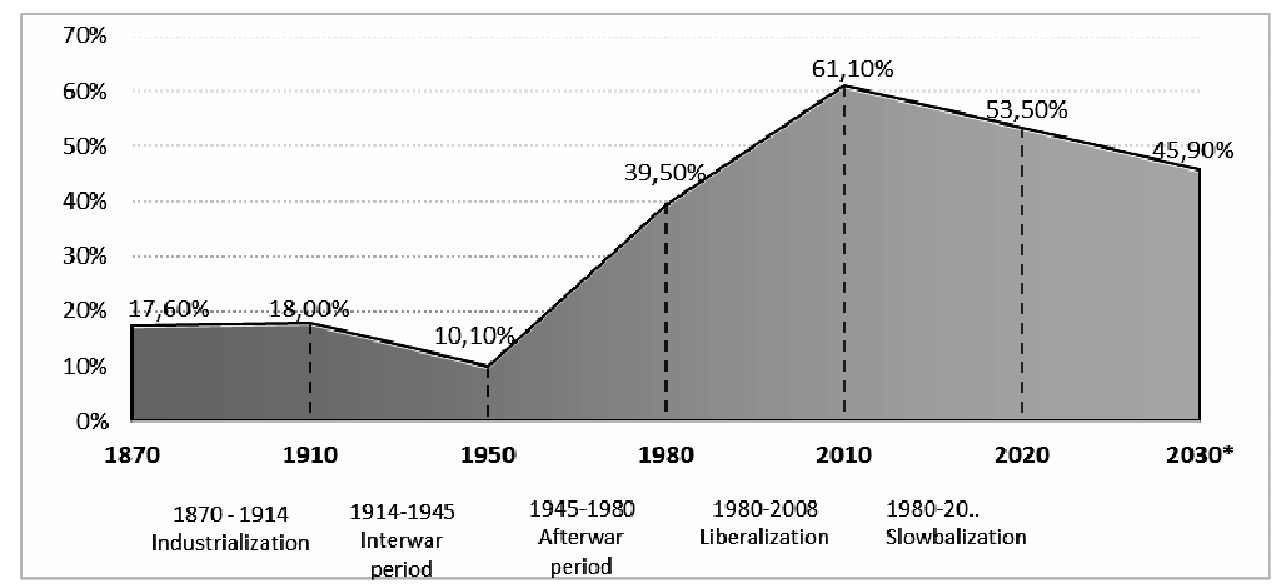

Source: created by the authors based on Ortiz-Ospina \& Beltekian (2018). Note*: 2030 - forecast values

As shown in figure 2, the World GDP growth slowed after the Great Recession (the economic downturn from 2007 to 2009) and then the World GDP growth transitioned into a regular decrease called «slowbalization» because of the reduction or stagnation of cross-border investments, trade, bank loans and supply chains.

The trend in the results of global exports of goods and services reveals a significant drop in the growth rates of globalization after 2014 (18.74 trillion USD) with a slight recovery in 2018 (19.26 trillion USD).

Globalization rates are different depending on whether they are recorded for high-income countries, low-middle income countries or low-income countries. Thus, the distinct tendency to reduced globalization (fig. 4) is found in lowincome countries (the correlation factor is greater than 0.8). Middle-income countries show this trend to a less evident degree (above 0.6 ) and high-income countries show the lowest degree (0.3). 
Figure 2

World GDP growth (annual), percentage

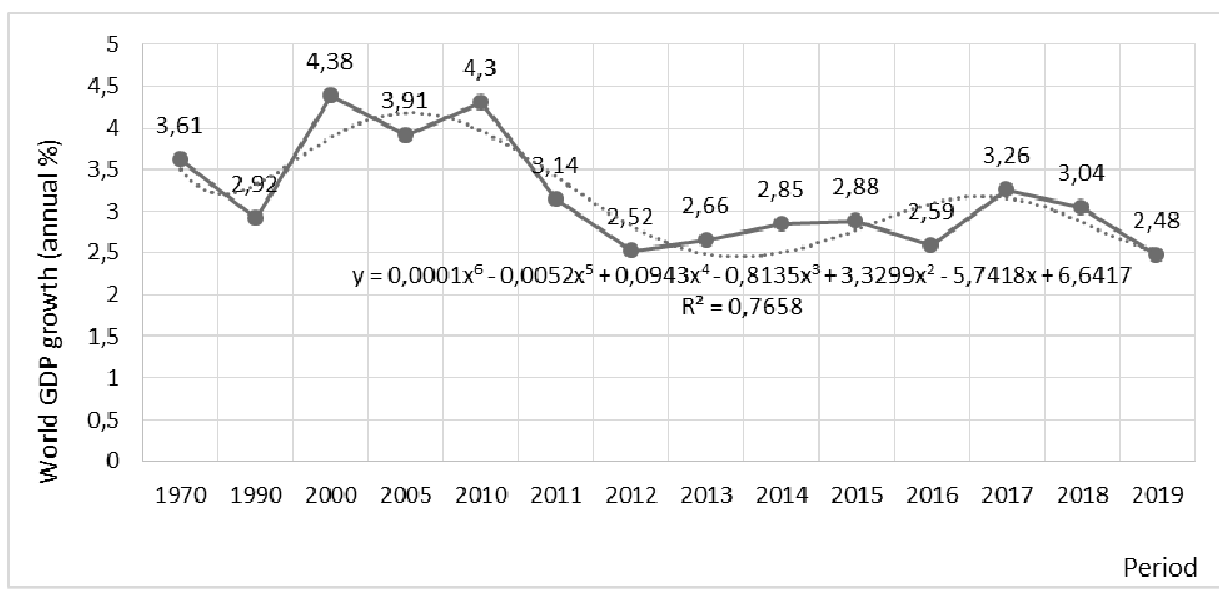

Source: created by the authors using the data of Knoema (2020).

Figure 3

\section{World exports of goods and services}

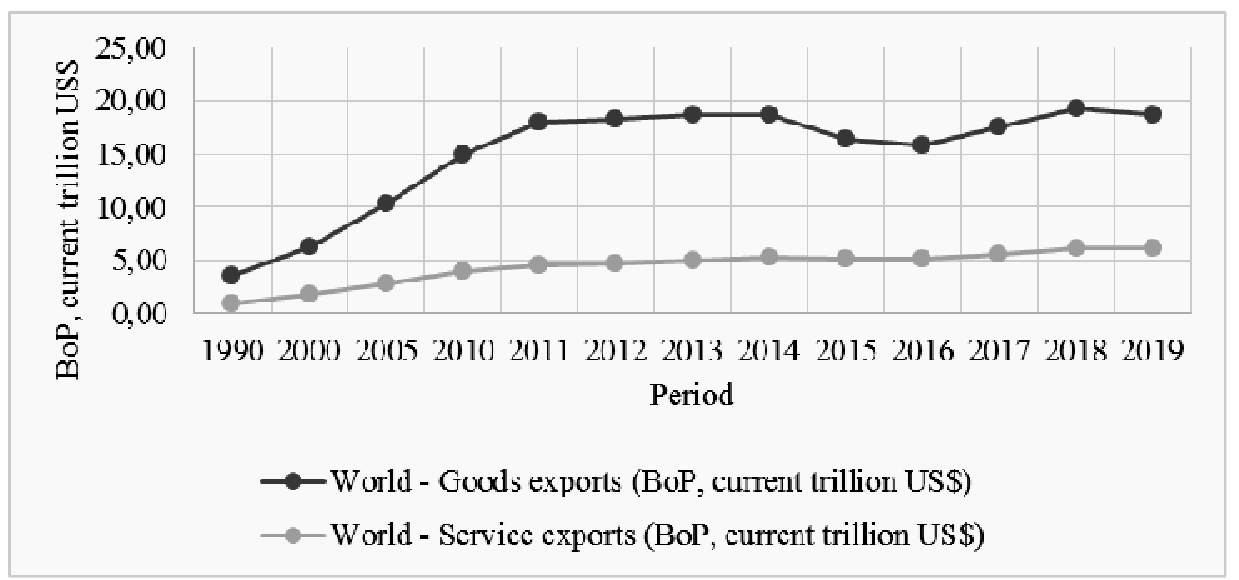

Source: created by the authors using the data of Knoema (2020). 
Figure 4

\section{Globalization rates in countries with various economic levels}

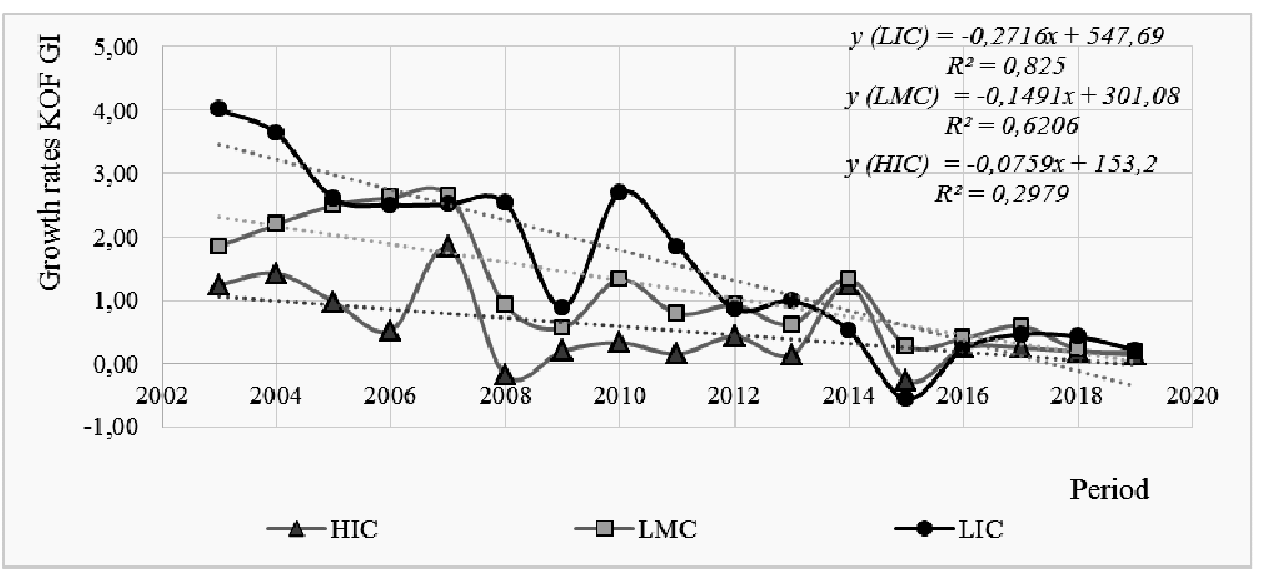

Source: created by the authors based on KOF Globalization Index (Gygli et al., 2019). Note: HIC - high income countries; LMC - lower-middle income countries; LIC - low income countries

Analysing economic growth forecasts by regions of the world (Table 1) leads to several observations:

- in the East Asia and Pacific region, economic growth fell to $+0.9 \%$, the lowest since 1967, in particular Cambodia fell to $-2.0 \%$, China fell to $+2.0 \%$, Indonesia fell to $-2.2 \%$, Malaysia fell to $-5.8 \%$, Thailand fell to $-6.5 \%$, and Vietnam fell to $+2.8 \%$;

- in Europe and Central Asia, economic growth fell to $-2,9 \%$, while recession occurred in almost all countries, Poland fell to $-3.4 \%$, Russian Federation to $-4.0 \%$, Tajikistan to $2.2 \%$, Turkey to $0.5 \%$, and Ukraine to $-5.5 \%$;

- in Latin America and the Caribbean region, economic growth fell to $-6.9 \%$, while Brazil fell to $-4.5 \%$, and Chile fell to $-6.3 \%$;

- in Advanced Economies, economic growth fell to $-5.4 \%$, while the United States fell to $-3.6 \%$, Euro area to $-7.4 \%$ and Japan to $-5.3 \%$;

- in South Asia, economic growth fell to $-6.7 \%$, in particullar Afghanistan fell to $-5.5 \%$, Bangladesh fell to $+2.0 \%$; Bhutan fell to $+0.7 \%$, India fell 
to $-9.6 \%$, Maldives fell to $-21.5 \%$, Nepal fell to $+0.2 \%$, Pakistan fell to $1.5 \%$, and Sri Lanka to $-6.7 \%$

- in Middle East and North Africa, economic growth fell to $-5.0 \%$, while Egypt fell to $+3.6 \%$, Iraq fell to $-9.5 \%$, Saudi Arabia fell to $-5.4 \%$, and United Arab Emirates fell to $-6.3 \%$;

- in Sub-Saharan Africa, economic growth fell to $-3.7 \%$, in particular Angola fell to $-4 \%$, Cameroon fell to $-2.5 \%$, Republic of Congo fell to $-8.9 \%$, Liberia fell to $-2.9 \%$, Mozambique fell to $-0.8 \%$, Namibia fell to $-7.9 \%$, Nigeria fell to $-4.1 \%$, and South Africa fell to $-7.8 \%$.

Table 1

The real GDP of the world regions and countries

\begin{tabular}{|c|l|l|l|l|l|}
\hline \multirow{2}{*}{ Region } & \multicolumn{4}{|l|}{ Annual estimates and forecasts (\%) } \\
\cline { 2 - 6 } & 2018 & 2019 & $2020^{\mathrm{e}}$ & $2021^{\mathrm{T}}$ & $2022^{\dagger}$ \\
\hline World & 3.0 & 2.3 & -4.3 & 4.0 & 3.8 \\
\hline Advanced economies & 2.2 & 1.6 & -5.4 & 3.3 & 3.5 \\
\hline United States & 3.0 & 2.2 & -3.6 & 3.5 & 3.3 \\
\hline Euro area & 1.9 & 1.3 & -7.4 & 3.6 & 4.0 \\
\hline Japan & 0.6 & 0.3 & -5.3 & 2.5 & 2.3 \\
\hline $\begin{array}{l}\text { Emerging markets } \\
\text { and developing economies }\end{array}$ & 4.3 & 3.6 & -2.6 & 5.0 & 4.2 \\
\hline East Asia and Pacific & & & & & \\
\hline Cambodia & 6.3 & 5.8 & 0.9 & 7.4 & 5.2 \\
\hline China & 7.5 & 7.1 & -2.0 & 4.0 & 5.2 \\
\hline Indonesia & 6.6 & 6.1 & 2.0 & 7.9 & 5.2 \\
\hline Malaysia & 5.2 & 5.0 & -2.2 & 4.4 & 4.8 \\
\hline Thailand & 4.7 & 4.3 & -5.8 & 6.7 & 4.8 \\
\hline Vietnam & 4.1 & 2.4 & -6.5 & 4.0 & 4.7 \\
\hline Europe and Central Asia & 7.1 & 7.0 & 2.8 & 6.7 & 6.5 \\
\hline Poland & 3.4 & 2.3 & -2.9 & 3.3 & 3.9 \\
\hline Russian Federation & 5.4 & 4.5 & -3.4 & 3.5 & 4.3 \\
\hline Tajikistan & 2.5 & 1.3 & -4.0 & 2.6 & 3.0 \\
\hline Turkey & 7.3 & 7.5 & 2.2 & 3.5 & 5.5 \\
\hline Ukraine & 3.0 & 0.9 & 0.5 & 4.5 & 5.0 \\
\hline Latin America and the Caribbean & 3.4 & 3.2 & -5.5 & 3.0 & 3.1 \\
\hline Brazil & 1.9 & 1.0 & -6.9 & 3.7 & 2.8 \\
\hline Chile & 1.8 & 1.4 & -4.5 & 3.0 & 2.5 \\
\hline Middle East and North Africa & 3.9 & 1.1 & -6.3 & 4.2 & 3.1 \\
\hline Egypt & 0.5 & 0.1 & -5.0 & 2.1 & 3.1 \\
\hline & 5.3 & 5.6 & 3.6 & 2.7 & 5.8 \\
\hline & & & & \\
\hline
\end{tabular}


Economic diplomacy strategy for the recovery of the slowdown of globalization (slowbalization)

\begin{tabular}{|c|c|c|c|c|c|}
\hline \multirow{2}{*}{ Region } & \multicolumn{5}{|c|}{ Annual estimates and forecasts (\%) } \\
\hline & 2018 & 2019 & $2020^{e}$ & $2021^{\dagger}$ & $2022^{\dagger}$ \\
\hline Iraq & -0.6 & 4.4 & -9.5 & 2.0 & 7.3 \\
\hline Saudi Arabia & 2.4 & 0.3 & -5.4 & 2.0 & 2.2 \\
\hline United Arab Emirates & 1.2 & 1.7 & -6.3 & 1.0 & 2.4 \\
\hline South Asia & 6.5 & 4.4 & -6.7 & 3.3 & 3.8 \\
\hline Afghanistan & 1.2 & 3.9 & -5.5 & 2.5 & 3.3 \\
\hline Bangladesh & 7.9 & 8.2 & 2.0 & 1.6 & 3.4 \\
\hline Bhutan & 3.8 & 4.3 & 0.7 & -0.7 & 2.3 \\
\hline India & 6.1 & 4.2 & -9.6 & 5.4 & 5.2 \\
\hline Maldives & 8.1 & 7.0 & -21.5 & 9.5 & 11.5 \\
\hline Nepal & 6.7 & 7.0 & 0.2 & 0.6 & 2.5 \\
\hline Pakistan & 5.5 & 1.9 & -1.5 & 0.5 & 2.0 \\
\hline Sri Lanka & 3.3 & 2.3 & -6.7 & 3.3 & 2.0 \\
\hline Sub-Saharan Africa & 2.6 & 2.4 & -3.7 & 2.7 & 3.3 \\
\hline Angola & -2.0 & -0.9 & -4.0 & 0.9 & 3.5 \\
\hline Cameroon & 4.1 & 3.7 & -2.5 & 3.0 & 3.4 \\
\hline Congo, Rep. & -6.2 & -3.5 & -8.9 & -2.0 & 1.3 \\
\hline Liberia & 1.2 & -2.3 & -2.9 & 3.2 & 3.9 \\
\hline Mozambique & 3.4 & 2.2 & -0.8 & 2.8 & 4.4 \\
\hline Namibia & 0.7 & -1.1 & -7.9 & 2.2 & 2.0 \\
\hline Nigeria & 1.9 & 2.2 & -4.1 & 1.1 & 1.8 \\
\hline South Africa & 0.8 & 0.2 & -7.8 & 3.3 & 1.7 \\
\hline
\end{tabular}

Source: adapted by the authors from World Bank. (2020). Global Economic Prospects. https://doi.org/10.1596/978-1-4648-1612-3

Note: $e=$ estimate; $f=$ forecast.

Economic diplomacy is considered important for three reasons. First, in several countries, the government has an active role in economic policy. Second, companies owned by the state can be the counterpart to an enterprise that operates in international markets. This requires entrepreneurs to seek cooperation with the national government. Third, the government can intervene to reduce or eliminate international transactions that cause problems. Economic diplomacy is being studied by the academic community and its relevance among policymakers increases its popularity.

One instrument that has emerged from economic diplomacy is the export promotion agencies (EPAs). EPAs belong to a governmental or state unit and play a key strategic role in helping companies looking to boost exports and increase trade through marketing, financial, research and publications support services. The reason behind government involvement is based on market failures 
and asymmetric information (Olarreaga et al., 2017). There is critical information to analyse and study before deciding to enter the foreign market, which includes business opportunities, establishing a network of contacts and a distribution chain, consumer needs, applied taxes and other costs associated with the business activities (Lederman et al., 2010; Hausmann \& Rodrik, 2003). The uncertainty regarding the different laws and regulations of the foreign market is presented as a reason for public sector support implemented through export insurance (Kneller \& Greenaway, 2005).

EPAs have an important goal, which is to increase the number of exporting companies, since economic development means participating in foreign markets. Participation in foreign markets can enhance the productivity of companies (Yang \& Mallick, 2010), due to the technical know-how provided by foreign companies and the highly competitive quality needed in international markets (Verhoogen, 2008), as well as the call for a diversification strategy to expand the number of markets where the company operates. Companies that have the know-how and innovative capabilities are more competitive in producing and selling goods and services (Hausmann et al., 2007; Higaldo et al., 2007).

EPAs can play a great role in helping small and medium-sized enterprises (SMEs) to expand to foreign markets. SMEs do not have large support structures, therefore, they need help to identify market opportunities and provide the company with the capacity to compete in the market, as only the most competitive ones reach the export stage (Melitz \& Redding, 2014).

Several studies show that EPAs have a positive impact in helping companies in promoting exports, in giving them the skills to enter and survive a foreign market, in giving them the know-how to make geographic and product diversification in foreign markets (Table 2).

Table 2

Export Promotion Research Studies

\begin{tabular}{|c|c|c|c|}
\hline $\begin{array}{l}\text { Enterprise } \\
\text { level studies } \\
\text { show: }\end{array}$ & Authors & Year & References: \\
\hline \multirow{2}{*}{$\begin{array}{l}\text { EPAS have a } \\
\text { positive im- } \\
\text { pact on ex- } \\
\text { port promo- } \\
\text { tion }\end{array}$} & $\begin{array}{l}\text { Alvarez \& } \\
\text { Crespi }\end{array}$ & 2000 & $\begin{array}{l}\text { Alvarez, R. E., \& Crespi, G. T. (2000). Exporter } \\
\text { Performance and Promotion Instruments: Chil- } \\
\text { ean Empirical Evidence. Estudios de Economía. }\end{array}$ \\
\hline & $\begin{array}{l}\text { Gorg, } \\
\text { Henry, \& } \\
\text { Strobl }\end{array}$ & 2008 & $\begin{array}{l}\text { Gorg, H., Henry, M., \& Strobl, E. (2008). Grant } \\
\text { Support and Exporting Activity. The Review of } \\
\text { Economics and Statistics, 90(1), 168-174. }\end{array}$ \\
\hline
\end{tabular}



of the slowdown of globalization (slowbalization)

\begin{tabular}{|c|c|c|c|}
\hline $\begin{array}{l}\text { Enterprise } \\
\text { level studies }\end{array}$ & Authors & Year & References: \\
\hline & Freixanet & 2012 & $\begin{array}{l}\text { Freixanet, J. (2012). Export promotion pro- } \\
\text { grams: Their impact on companies' internation- } \\
\text { alization performance and competitiveness. In- } \\
\text { ternational Business Review, 21(6), 1065-1086. } \\
\text { https://doi.org/10.1016/j.ibusrev.2011.12.003 }\end{array}$ \\
\hline & $\begin{array}{l}\text { Geldres- } \\
\text { Weiss \& } \\
\text { Carrasco- } \\
\text { Roa }\end{array}$ & 2016 & $\begin{array}{l}\text { Geldres-Weiss, V. V., \& Carrasco-Roa, J. A. } \\
\text { (2016). Impact evaluation of national export } \\
\text { promotion programs on export firms using con- } \\
\text { trast groups. International Journal of Export } \\
\text { Marketing, 1(1), 77-95. }\end{array}$ \\
\hline \multirow{4}{*}{$\begin{array}{l}\text { Enterprise's } \\
\text { capacity to } \\
\text { enter and } \\
\text { survive in } \\
\text { foreign mar- } \\
\text { kets }\end{array}$} & Cruz & 2014 & $\begin{array}{l}\text { Cruz, M. (2014). Do Export Promotion Agencies } \\
\text { Promote New Exporters? The World Bank. } \\
\text { https://doi.org/10.1596/1813-9450-7004 }\end{array}$ \\
\hline & $\begin{array}{l}\text { Lederman } \\
\text { et al. }\end{array}$ & 2016 & $\begin{array}{l}\text { Lederman, D., Olarreaga, M., \& Zavala, L. } \\
\text { (2016). Export promotion and firm entry into and } \\
\text { survival in export markets. Canadian Journal of } \\
\text { Development Studies, } 37(2), \quad 142-158 . \\
\text { https://doi.org/10.1080/02255189.2016.1131671 }\end{array}$ \\
\hline & $\begin{array}{l}\text { Broocks } \\
\text { \& Van Bi- } \\
\text { ese- } \\
\text { broeck }\end{array}$ & 2017 & $\begin{array}{l}\text { Broocks, A., \& Van Biesebroeck, J. (2017). The im- } \\
\text { pact of export promotion on export market entry. } \\
\text { Journal of International Economics, 107, 19-33. } \\
\text { https://doi.org/10.1016/j.jinteco.2017.03.009 }\end{array}$ \\
\hline & $\begin{array}{l}\text { Munch \& } \\
\text { Schaur }\end{array}$ & 2018 & $\begin{array}{l}\text { Munch, J., \& Schaur, G. (2018). The effect of ex- } \\
\text { port promotion on firm-level performance. American } \\
\text { Economic Journal: Economic Policy, 10(1), 357- } \\
\text { 387. https://doi.org/10.1257/pol.20150410 }\end{array}$ \\
\hline \multirow{3}{*}{$\begin{array}{l}\text { Geographic } \\
\text { as well as } \\
\text { product di- } \\
\text { versification }\end{array}$} & $\begin{array}{l}\text { Alvarez \& } \\
\text { Crespi }\end{array}$ & 2000 & $\begin{array}{l}\text { Alvarez, R. E., \& Crespi, G. T. (2000). Exporter } \\
\text { performance and promotion instruments: Chil- } \\
\text { ean empirical evidence. Estudios de Economía }\end{array}$ \\
\hline & $\begin{array}{l}\text { Volpe } \\
\text { Martincus } \\
\text { \& Car- } \\
\text { ballo }\end{array}$ & 2010 & $\begin{array}{l}\text { Volpe Martincus, C., Estevadeordal, A., Gallo, } \\
\text { A., \& Luna, J. (2010). Information barriers, ex- } \\
\text { port promotion institutions, and the extensive } \\
\text { margin of trade. Review of World Economics, } \\
146(1), 91-111 \text {. https://doi.org/10.1007/s } 10290- \\
009-0043-0\end{array}$ \\
\hline & $\begin{array}{l}\text { Cadot et } \\
\text { al. }\end{array}$ & 2015 & $\begin{array}{l}\text { Cadot, O., Fernandes, A. M., Gourdon, J., \& } \\
\text { Mattoo, A. (2015). Are the benefits of export } \\
\text { support durable? Evidence from Tunisia. Jour- } \\
\text { nal of International Economics, 97(2), 310-324. } \\
\text { https://doi.org/10.1016/j.jinteco.2015.07.005 }\end{array}$ \\
\hline
\end{tabular}


English Edition. Vol. 20. № 2 (77). April-June 2021.

ISSN 2519-4070

\begin{tabular}{|c|c|c|c|}
\hline $\begin{array}{l}\text { Enterprise } \\
\text { level studies }\end{array}$ & Authors & Year & References: \\
\hline & $\begin{array}{l}\text { Volpe } \\
\text { Martincus } \\
\text { \& Car- } \\
\text { ballo }\end{array}$ & 2010 & $\begin{array}{l}\text { Volpe Martincus, C. V., \& Carballo, J. (2010). } \\
\text { Entering new country and product markets: } \\
\text { Does export promotion help? Review of World } \\
\text { Economics, } 146(3), 437-467 \text {. }\end{array}$ \\
\hline \multirow{3}{*}{$\begin{array}{l}\text { EPAs have a } \\
\text { positive ef- } \\
\text { fect on the } \\
\text { competences } \\
\text { of small } \\
\text { businesses }\end{array}$} & $\begin{array}{l}\text { Volpe } \\
\text { Martini- } \\
\text { cus \& } \\
\text { Carballo }\end{array}$ & 2010 & $\begin{array}{l}\text { Volpe Martincus, C., \& Carballo, J. (2010). Beyond } \\
\text { the average effects: The distribution impacts of ex- } \\
\text { port promotion programs in developing countries. } \\
\text { Journal of Devel. Economics, 92(2), 201-214. } \\
\text { https://doi.org/10.1016/j.jdeveco.2009.02.007 }\end{array}$ \\
\hline & $\begin{array}{l}\text { Leonidou } \\
\text { et al. }\end{array}$ & 2014 & $\begin{array}{l}\text { Leonidou, L. C., Samiee, S., \& Geldres, V. V. } \\
\text { (2014). Using national export promotion programs } \\
\text { to assist smaller firm's international entrepreneu- } \\
\text { rial initiatives. In P.N. Ghauri, \& V.H.M. Kirpalani } \\
\text { (Eds.), Handbook of research on international en- } \\
\text { trepreneurship strategy: Improving SME perform- } \\
\text { ance globally. Edward Elgar Publishing Ltd. } \\
\text { https://doi.org/10.4337/9781783471584.00023 }\end{array}$ \\
\hline & $\begin{array}{l}\text { Munch \& } \\
\text { Schaur }\end{array}$ & 2018 & $\begin{array}{l}\text { Munch, J., \& Schaur, G. (2018). The effect of ex- } \\
\text { port promotion on firm-level performance. Ameri- } \\
\text { can Economic Journal: Economic Policy, 10(1), } \\
\text { 357-387. https://doi.org/10.1257/pol.20150410 }\end{array}$ \\
\hline
\end{tabular}

Source: created by the authors based on De Falcis et al. (2018).

Rose (2007) is an exception in studies on the impact of EPAs on exports. Rose estimated the impact of economic diplomacy (embassies or consulates) on exports and concluded that for each new consulate abroad, exports go up 6 to $10 \%$. Nevertheless, Rose affirms that embassies and consulates have lost importance in decision-making due to low communication costs and, therefore, turning embassies and consulates into export promotion agents.

\section{Conclusions}

In the current economic context, the movement against globalization caused by the growing dissatisfaction with income inequality has increased the popularity of protectionist trade policies. In 2017, the G20 countries were unable to guarantee the maintenance of free trade commitments and avoid protection- 

of the slowdown of globalization (slowbalization)

ism. These changes could lead to more protectionist measures that could create barriers to free trade and corrupt the multilateral rules architecture that has been adopted since 1940s (Lakatos \& Kutlina-Dimitrova, 2017).

There is a high probability of a return to protectionism that will be the countries' response to global challenges. It is expected that the countries' trade policy will become more conservative and will result, perhaps, in new measures to implement more import tariffs and more non-tariff barriers (licensing, import quotations). National economies may even try to protect some national industries.

To reap the benefits of globalization, governments must continue to eradicate inequalities in world trade, eliminate trade barriers and implement a fairer trade system, with a focus on diplomatic policy.

If we imagine a scenario to quantify the impact of protectionist measures in which all trade agreements were withdrawn and there was a 3 percent increase in commercial services, that would mean a 40 percent increase in average global tariff rates from 2.7 to 3.8 percent. This is a purely hypothetical scenario, but it captures the consequences of further protectionism (Lakatos \& Kutlina-Dimitrova, 2017).

Globalization was made possible by a market with liberalization of trade and elimination of cross-borders barriers, free flows of goods, capital, technology, data, human capital and the support of the state when the market had failures. After the Second World War, globalization became slowbalization due to a growing protectionism and the stagnation of cross-border investments, trade, bank loans and supply chains.

The pandemic crisis needs special measures to protect companies and families through economic diplomacy. Economic diplomacy could help in slowbalization (slowdown scenario) through the implementation of bilateral, regional and multilateral agreements. Embassies and consulates are agents of export promotion and it is estimated that a presence of a consulate or embassy could increase the exports by 6 percent to 10 percent (Rose, 2007).

EPAs are also a powerful instrument of national governments to promote and increase exports. In the last decades, the structure of EPAs has changed and become more export oriented. EPAs have real impact on national exports. The estimates suggest that a 10 percent increase in EPA's budget increases exports by 0.6 to 1 percent. In addition, EPAs have an important role to play in overcoming trade barriers or rectifying asymmetric information. EPAs have a positive impact on export promotion, on the company's ability to enter and survive in foreign markets, on geographic and product diversification, and on the competences of small businesses.

Successful EPAs, that is, those with the largest national exports, are those from the private sector, but with a large share of public sector financing. A robust 
EPA is better than having several small agencies and has an influence on increasing exports.

Economic diplomacy is the key to defining national and international policies, to boosting trade and investments and to resolving international disputes. The agenda of economic diplomacy includes import and export relations, expansion of economic interests and negotiation of trade agreements and commercial cooperation. EPAs are instrumental in helping SMEs to expand to foreign markets and, therefore, to increase exports and investments.

\section{References}

Bakas, A. (2015). Capitalism \& Slowbalization: The Market, the State and the Crowd in the 21st Century. Dexter.

Bayne, N. \& Woolcock, S. (2016). The new economic diplomacy: Decision making and negation in international economic relations (4th ed.). Taylor \& Francis Group.

Bergeijk, P. A., Okano-Heijmans, M., \& Melissen, J. (Eds.). (2011). Economic diplomacy: economic and political perspectives (Vol. 1). Martinus Nijhoff Publishers.

Campbell, D. (1994). Foreign investment, labour immobility and the quality of employment. International Labour Review, 133(2), 185-188.

De Falcis, E., Valentina, R., Solleder, O., \& Ticku, R. (2018). What bang for the buck? Export promotion and trade extensive margin. ITC Working Paper Series, WP-02-2018.E. https://www.intracen.org/uploadedFiles/intracenorg/ Content/Redesign/Projects/SME_Competitiveness/TPO\%20-\%20WP-022018.E.pdf

Dicken, P. (1992). Global shift: The internationalization of economic activity. Paul Chapman Publishing Ltd.

Flissak, K. (2015). Economic diplomacy mechanism: World experience and Ukraine. Journal of global economy review, 2(1), 26-33. https://mogmat.uowm.gr/ wpcontent/uploads/sites/19/2021/03/JGER_2_2015.pdf\#page=27

Gygli, S., Haelg, F., Potrafke, N., \& Sturm, J.-E. (2019). The KOF Globalisation Index - revisited. Review of International Organizations, 14(3), 543-574. https://doi.org/10.1007/s11558-019-09344-2

Hausmann, R., Hwang, J., \& Rodrik, D. (2007). What you export matters. Journal of economic growth, 12(1), 1-25. https://doi.org/10.1007/s10887-006-9009-4 

of the slowdown of globalization (slowbalization)

Hausmann, R., \& Rodrik, D. (2003). Economic development as selfdiscovery. Journal of development Economics, 72(2), 603-633.

Hidalgo, C. A., Klinger, B., Barabási, A. L., \& Hausmann, R. (2007). The product space conditions the development of nations. Science, 317(5837), 482487. http://dx.doi.org/10.1126/science.1144581

Kneller, R., \& Greenaway, D. (2005). Firm heterogeneity, exporting and foreign direct investment: A survey. University of Nottingham Research Paper Series, 2005/32. http://dx.doi.org/10.2139/ssrn.863964

Knoema. (2020). National accounts main aggregates database (Version of December 16, 2020) [Data set]. https://knoema.ru/UNNAMAD2018/nationalaccounts-main-aggregates-database.

Lakatos, C., \& Kutlina-Dimitrova, Z. (2017). The global costs of protectionism. Policy Research Working Paper, No. 8277. http://documents.worldbank.org/ curated/en/962781513281198572/The-global-costs-of-protectionism

Lederman, D., Olarreaga, M., \& Payton, L. (2010). Export promotion agencies: Do they work?. Journal of development economics, 91(2), 257-265. https://doi.org/10.1016/j.jdeveco.2009.09.003

Melitz, M. J., \& Redding, S. J. (2014). Heterogeneous firms and trade. In G. Gopinath, E. Helpman, \& K. Rogoff, (Eds.), Handbook of International Economics. Elsevier.

Milanovic, B. (2012). Global income inequality by the numbers: In history and now - An overview. World Bank Policy Research, Working Paper 6259. https://doi.org/10.1596/1813-9450-6259

Okano-Heijmans, M. (2011). Conceptualizing economic diplomacy: The crossroads of international relations, economics, IPE and diplomatic studies. The Hague journal of diplomacy, 6(1-2), 7-36. http://dx.doi.org/10.1163/ $187119111 \times 566742$

Olarreaga, M., Sperlich, S., \& Trachsel, V. (2017). Export promotion: What works?. FERDI Working Paper, No. 184. https://ferdi.fr/dl/df-N3jtnfSNX3Ea QeYSq1tdSCzv/ferdi-p184-export-promotion-what-works.pdf

Oxford Economics. (2011). The new digital economy: How it will transform business. https://www.pwc.com/cl/es/publicaciones/assets/the-new-digital-economy.pdf

Ortiz-Ospina, E., \& Beltekian, D. (2018). Trade and globalization. Our World in Data. https://ourworldindata.org/trade-and-globalization

Rose, A. K. (2007). The foreign service and foreign trade: embassies as export promotion. World Economy, 30(1), 22-38.

Saner, R., \& Yiu, L. (2003). International economic diplomacy: Mutations in postmodern times. Discussion Papers in Diplomacy, No. 84. 
http://www.businessdiplomats.com/images/articles/files/Postmodern_diplomacy.pdf

Sharov, O. (2018). Economic diplomacy as a symbiosis of science and politics. International Economic Policy, 1, 64-87. http://iepjournal.com/ journals_eng/28/2018_3_Sharov.pdf

van Bergeijk, P. A. G. (2009). Economic diplomacy and the geography of international trade. Edward Elgar Publishing

Verhoogen, E. A. (2008). Trade, quality upgrading, and wage inequality in the Mexican manufacturing sector. The Quarterly Journal of Economics, 123(2), 489-530. https://doi.org/10.1162/qjec.2008.123.2.489

World Bank (2020). Global Economic Prospects. https://doi.org/10.1596/978-14648-1612-3

Yang, Y., \& Mallick, S. (2010). Export premium, self-selection and learning-byexporting: Evidence from Chinese matched firms. The World Economy, 33(10), 1218-1240. https://doi.org/10.1111/j.1467-9701.2010.01277.x

Received: April 20, 2021.

Reviewed: April 27, 2021.

Accepted: May 17, 2021. 